\title{
ON SOME CHILOPODS FROM BARRO COLORADO ISLAND
}

\author{
By Ralph V. Chamberlin \\ University of Utah.
}

The humus dwelling chilopods listed in the present paper constitute a collection made by Mr. Eliot C. Williams, Jr., of Northwestern University, on Barro Colorado Id., Panama, in July and August, 1938, with the exception of Taeniolinum panamicum, the representative of which was taken in the Changuinola District by F. R. Swift. The types of the new forms are in the author's collection.

\section{CRYPTOPID $Æ$}

\section{Newportia rogersi Pocock}

Newportia rogersi Pocock, Biol. Centr. Amer. Chilopoda, 1896, p. 33, pl. 3, figs. 6-6d.

Newportia rogersi, Chamberlin, Proc. U. S. Nat. Mus., 1922, vol. 60, art. 7, p. 5 .

Twelve partly grown specimens of this species were taken at different dates in August. It was previously reported from Costa Rica at Volcan de Irazu (type locality), Cocos and San José.

\section{SCUTIGERIDA \\ Pselliodes sp.}

One young specimen was taken Aug. 9. It is possibly $P$. nigrovittata (Meinert), for which Panama is the type locality.

\section{SCHENDYLIDE}

Schendylurus (Schendylotyn) integer Chamberlin Schendylurus (Schendylotyn) integer Chamberlin, Proc. Biol. Soc. Wash., 1926, vol. 39, p. 10. 
One specimen was taken on Sept. 3. Barro Colorado Id. is the type locality for this species, the holotype, a male, having been taken from a nest of the termite Anoplotermes gracilis Snyder by James Zetek, 30 Oct., 1924.

\section{BALLOPHILIDFE}

Assuming that the inadequately known genotype of Tæniolinum belongs to the Ballophilidæ, as seems reasonably certain, and that it is congeneric with the form hereafter described as $T$. panamicus, the known genera of this family may be separated by means of the following key.

\section{Key to Genera of Ballophilida}

a. Ventral pores condensed, in one or two sharply limited and usually more or less elevated areas.

b. Ventral pores in a single, undivided field.

c. Antennae clavate.

d. Prehensors lacking chitinous lines. Ballophilus Cook

dd. Chitinous lines present on prosternum of prehensors.

e. Coxae of last legs with a single pore on each side; tergites bisulcate. Tanophilus Chamberlin ee. Pores of last coxae two on each side; tergites not bisulcate.

f. Field of ventral pores transversely elliptic.

Thalthybius Attems

ff. Field of ventral pores strictly circular.

Ityphilus Cook

cc. Antennae short, distally attenuated._._Leptynophilus, gen. nov. bb. Ventral pores in two circular areas on each sternite.

Diplethmus Cook

aa. Ventral pores diffuse, in an indistinctly limited band over caudal boarder; joints broader than long. Antennae short and thick.

Taniolinum Pocock

\section{Diplethmus dux, sp. nov.}

The general color of the body is olivaceous, the integument above being brown with dense green pigment showing through from beneath, the integument of sides and venter paler. Legs green.

Differs from $D$. ribauti, sp. nov., in the conspicuously broader head, in the constantly smaller number of pairs of legs (69 as against 77-79), etc. The head is more nearly of the proportions represented for the head of $D$. mexicanus 
Cook, the genotype. Head conspicuously convexly bulging at the sides, with anterior margin angled at middle and posterior margin straight.

The antennæ more definitely clavate than in mexicanus, the distal half being considerably thicker than the filiform proximal half of the organ; distinctly geniculate.

Prehensors when closed nearly even with anterior margin of head; claws slender; prosternum with chitinous lines distinct, the anterior border deeply angularly excavated at middle.

Porigerous areas of ventral plates circular, one close to each lateral margin and caudad of middle of plate, this elevated porigerous area relatively smaller than in ribauti, but clearly larger than represented for mexicanus and very much closer to the caudal margin of plate.

Dorsal plates densely coarsely granular, not sulcate. Last dorsal plate covering pleuræ from above, elongate shieldshaped.

Last ventral plate somewhat longer than wide, narrowed caudad, a longitudinal median depression. Pores of coxopleuræ typical.

Last legs strongly crassate, but narrowing distally.

Pairs of legs 69 in the three type specimens.

Length of holotype, about $45 \mathrm{~mm}$.

Locality.-Panama: Barro Colorado Id. Three specimens of which the holotype, a male, was taken July 13, 1938.

\section{Diplethmus ribauti, sp. nov.}

Diplethmus mexicanus Ribaut (not of Cook), Mem. Soc. Neuchatel, vol. 5, p. 90, figs. 26-37.

Diplethmus mexicanus Chamberlin (not of Cook), Occ.

Papers Mus. of Zool., Univ. of Michigan, 1921, p. 17.

Prof. Ribaut, in the place above cited, has given a detailed and fully illustrated account of this species. Cook's description of mexicanus, embraced in a key, is confined to the following: "Ventral pores in two areas; antennæ subfiliform; Genus Diplethmus, type D. mexicanus, sp. n. (Pl. V, fig. 2), Mexico." The figures given are the only means of identification. The differences these show in size of the 
porigerous area, in the shape of the head, and in the more elongate last sternite, would seem to make it impossible longer to consider the Colombian specimens as belonging to mexicanus since the characters mentioned are constant. Accordingly, a new name is here proposed for the Colombian species described by Ribaut.

Localities.-Colombia: Camelia, near Angelopolis; San Lorenzo. A male taken at the latter place from a bromeliad on a tree at 5,000 ft. elevation July 22, 1913, may be designated as the holotype. It is in the Museum of Comparative Zoology at Cambridge. A second male was taken at the latter locality under a log at 2,000 ft. elevation on July 25, 1913.

\section{Taeniolinum panamicum, sp. nov.}

In general characters much resembling T. setosum Pocock of St. Vincent; but the similarly short antennæ are slightly clavate instead of distinctly narrowing distad. The head appears to be more rounded anteriorly. The anal legs are similarly very thick proximally, narrowed distad, the last joint conical. The ventral pores are relatively sparse and are arranged across posterior border of the sternites, the poriferous area not sharply defined. Last ventral plate of moderate width, about as represented for T. setosum, similarly narrowing caudad. Two large coxal pores on each anal coxa, these partly covered by the last plate.

Pairs of legs, 45 .

Length, $11 \mathrm{~mm}$.

Locality.-Panama: Changuinola District, Boc Taso. One male taken by F. R. Swift. The only other known species of the genus is the genotype, T. setosum Pocock, described from St. Vincent and not since reported.

\section{Leptynophilus, gen. nov.}

Among the known genera of Ballophilidæ agreeing with Ballophilus and differing from all others in lacking chitinous lines on the prosternum of the prehensors. It may readily be distinguished from Ballophilus, as also from all the other genera excepting Tæniolinum, in having the antennæ attenuated instead of more or less clavately thick- 
ened. Tergites not bisulcate. Ventral pores in a large transversely elliptic area. Coxal pores of last segment two on each side.

Genotype.-L. mundus Chamberlin, sp. nov.

Leptynophilus mundus, sp. nov.

The type as at present, after preservation in alcohol, is fulvous and shows no dark pigmentation in the deeper tissues except in connection with the ventral glands.

Head small, widest behind and narrowed forward, anteriorly rounded. Antennæ short, attenuated beyond middle; first 5 or 6 joints longest, those beyond very short, the ultimate about equal in length to the two preceding taken together; a little curved at middle but not truly geniculate.

Claws of prehensors when closed not attaining the front margin of the head by a considerable distance. Chitinous lines absent. Anterior margin of prosternum gently incurved. Claws smooth.

Body constricted a little back of head as usual. Dorsal plates not bisulcate, clothed with numerous but not dense short setæ. Last dorsal plate anteriorly broad, strongly narrowing caudad.

Spiracles round, small, very gradually decreasing in size from the first caudad.

Ventral plates conspicuously setose. The ventral pores in a sharply defined, large, transversely elliptic area behind middle of sternite.

Last ventral plate broader than long, strongly narrowed caudad. Coxal pores large, two on each side.

Anal legs much swollen as usual in related genera, the ultimate article small, conically pointed.

Pairs of legs, 51.

Length, $23 \mathrm{~mm}$.

Locality.-Panama: Barro Colorado Id.

Differs from Tæniolinum setosum in the longer, more slender antennæ, in the relatively broader and shorter last sternite, and in the larger size, the length of $T$. setosum being given as $13 \mathrm{~mm}$. 


\section{PACHYMERINIDE}

\section{Polycricus fossor, sp. nov.}

Color, pale yellow throughout.

Spiracles circular, the first much larger than the second which is intermediate in size.

Cephalic plate longer than wide, of nearly uniform width between the oblique corners; caudal margin straight. Frontal suture not evident. Antennæ short, filiform, uniformly setose, the ultimate article equalling or a little exceeding the two preceding taken together. Two very small, pale clypeal areas each bearing a single seta. Median division of labrum bearing 5 stout teeth, the lateral pieces conspicuously pectinate. Lappets of first maxillæ long and conspicuous. Coxæ of second maxillæ widely joined at middle; no coxopleural sutures evident.

Claws of prehensors when closed considerably surpassing the end of the first antennal joint. Claw at base and femur at distal end with a minute denticle, the other articles unarmed. Prosternum without chitinous lines.

Ventral pores in a band across caudal border of sternites.

Last ventral plate narrow. Coxopleural pores small and numerous as usual.

Pairs of legs, 71.

Length, about $15 \mathrm{~mm}$.

Locality.-Panama: Barro, Colorado. Aug. 6, 1938. One specimen.

Differs from $P$. stolli (Pocock) in having two clypeal areas instead of one, in number of pairs of legs, etc.

\section{CHILENOPHILID $A$}

Barrophilus, gen. nov.

A genus apparently most closely related to the African Polygonarea. With this genus it agrees in the structure of the second maxillæ the coxæ of which are connected only by a narrow membranous isthmus and are produced into a conspicuous conical process at the distomesal corner, the coxopleural suture running also as in that genus. Clypeal area present, single. Median dentate division of labrum 
widely separating the pectinate lateral pieces. Last coxæ with peculiar setose lobes much as in Polygonarea. It differs from Polygonarea in lacking external lappets on the first maxillæ, and in lacking ventral pores on the sternites. Anal legs with terminal claw.

Genotype.-B. isolatus, sp. n.

\section{Barrophilus isolatus, sp. $\mathrm{n}$.}

Yellow throughout, the head scarcely darker.

Cephalic plate longer than wide in the usual ratio and of the typical general shape, being widest at caudal level of frontal region from where strongly narrowing cephalad and moderately caudad to the oblique caudal corners; posterior margin straight. A true frontal suture not present. Last two articles of antennæ equalling or a little surpassing the two preceding taken together. A median clypeal area far forward at anterior end, this bearing four setæ; setæ elsewhere absent from clypeus. Labrum distinctly tripartite, the lateral pieces pectinate; the median piece dentate, about half as long as each lateral piece.

First maxillæ without external lappets; outer branch much exceeding the inner branch. Coxa of second maxillæ strongly produced at disto-mesal angle into a conspicuous conical process; coxæ separated at middle, there being a narrow, membranous and glabrous isthmus; coxopleural suture long, running ectad of each pore as in Suturodes; claw of palpus wholly smooth.

Basal plate widely overlapped by the cephalic. Claws of prehensors when closed nearly attaining the distal end of the second antennal article. Claw article at base and femuroid armed within with an acute, conical black tooth, the intermediate articles not armed. Prosternum without chitinous lines; anterior margin with median excision, unarmed.

Spiracles small, circular.

Anterior sternites with a median longitudinal sulcus; no ventral pores detected.

Last ventral plate very wide with the posterior corners strongly rounded.

Coxopleuræ of the last legs with three glands on each side opening along border of last sternite. Adjacent to 
posterior end of sternite on each side and in relation to caudal gland a ventrally projecting small setose lobe which is farther forward on the joint and apparently less strongly developed than in species of Polygonarea.

Anal pores conspicuous.

Anal legs ending in well developed claws.

Number of pairs of legs 41 in all three types.

Length, $15 \mathrm{~mm}$.

Locality.-Panama: Barro Colorado Id., July 25 and 26 and Aug. 7, 1938, one specimen on each date.

Nabocodes, gen. nov.

Clypeal area single, far forward. Lateral pieces of labrum relatively short and broad, pectinate, widely separated by the median piece. Telopodite of first maxillæ biarticulate, without external lappets. Coxæ of second maxillæ only narrowly and weakly joined at middle; the pleurosternal line long, running ectad of the mesally open pore. Prehensors long, exposed from above; claw and femoral joints armed within; no chitinous lines developed. Ventral plate absent. Last dorsal plate normally broad. Last ventral plate broad. Coxal pores small, typically few along and beneath ventral plate. Anal pores present. Anal legs without claw.

Genotype.-Nabocodes mimellus Chamberlin, sp. n.

This genus differs from the African Brachygonarea in lacking lappets on the first maxillæ and in having the anal legs clawless. It differs from Barrophilus in lacking the processes from meso-anterior corners of the coxæ of the second maxillæ, in lacking claws on the anal legs, and in the character of the coxal pores.

Nabocodes mimellus Chamberlin, sp. nov.

Pale yellow, with head and prehensors of slight chestnut cast.

The head of shape and proportions similar to that of the preceding species, but with anterior corners more obliquely rounded.

Claws of prehensors when closed attaining distal end of 
second antennal article. Claw armed at base with an acute tooth longer than in fossor and the tooth of femur also larger than in the latter species.

Spiracles round, the first largest. Sternites with a longitudinal sulcus which is widest and deepest at middle.

Anal sternite broad, the sides convex; with posterior corners rounded and middle portion of caudal margin straight. Coxal pores small and few, along and beneath edge of sternite, absent laterally and above.

Anal pores distinct.

Pairs of legs, in female holotype, 49.

Length, about $17 \mathrm{~mm}$.

Locality.-Panama: Barro Colorado Id. 


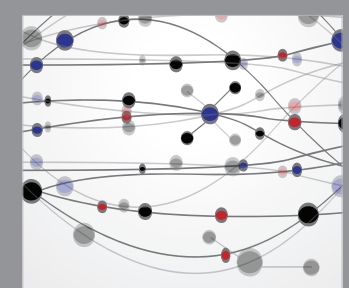

The Scientific World Journal
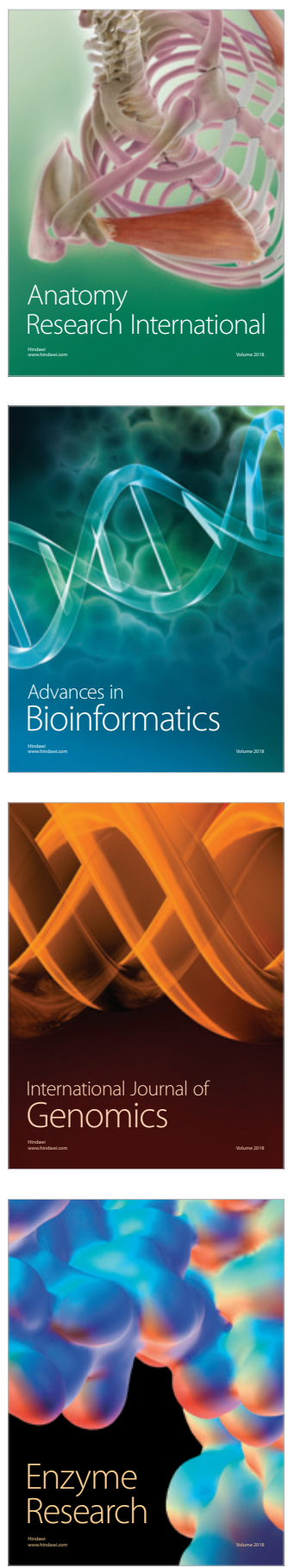
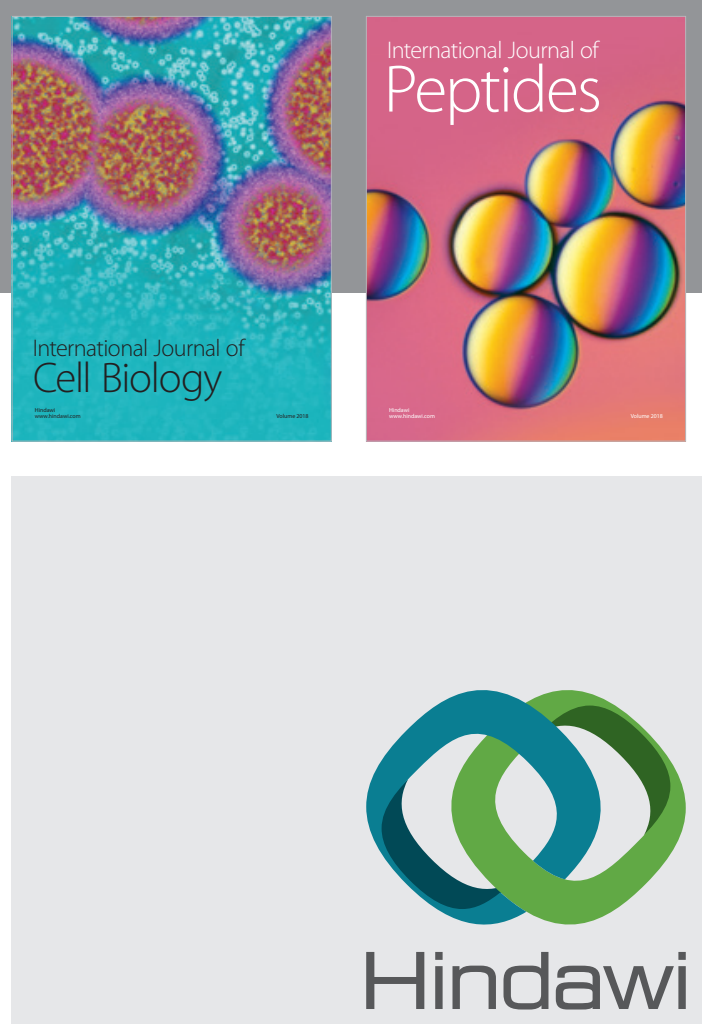

Submit your manuscripts at

www.hindawi.com
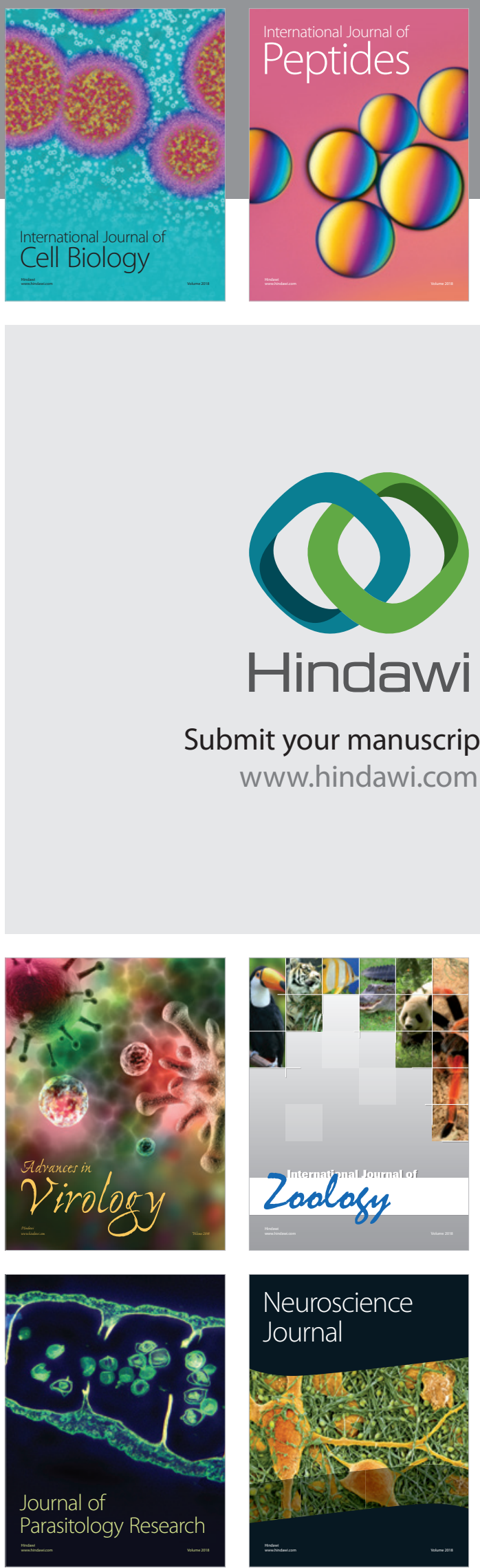
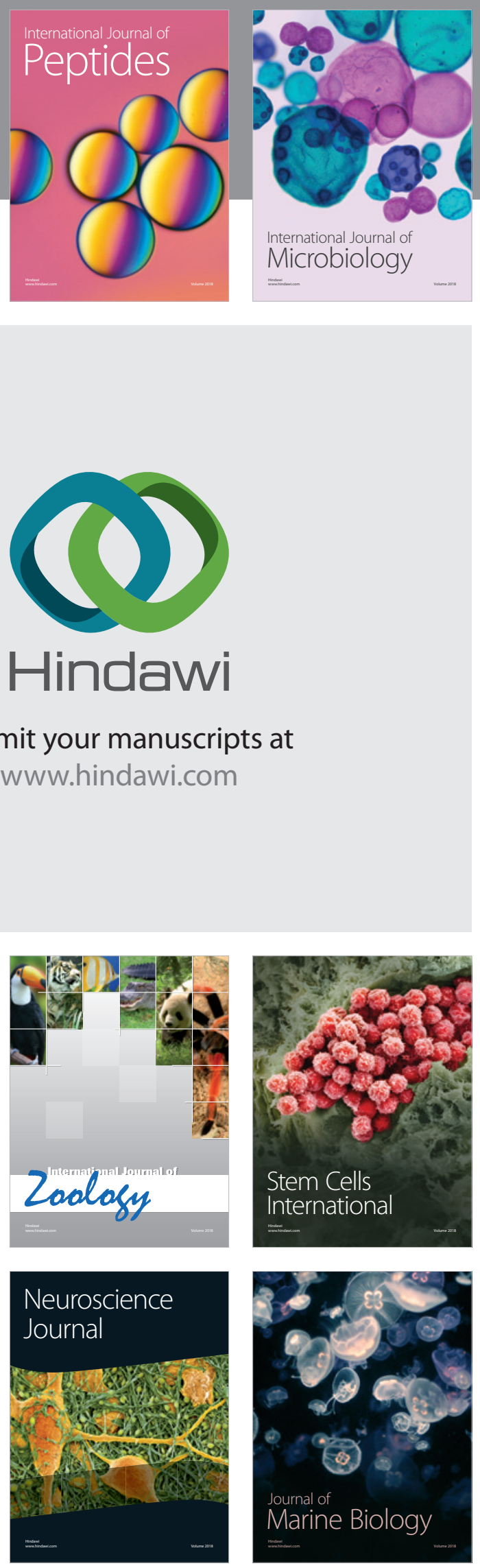
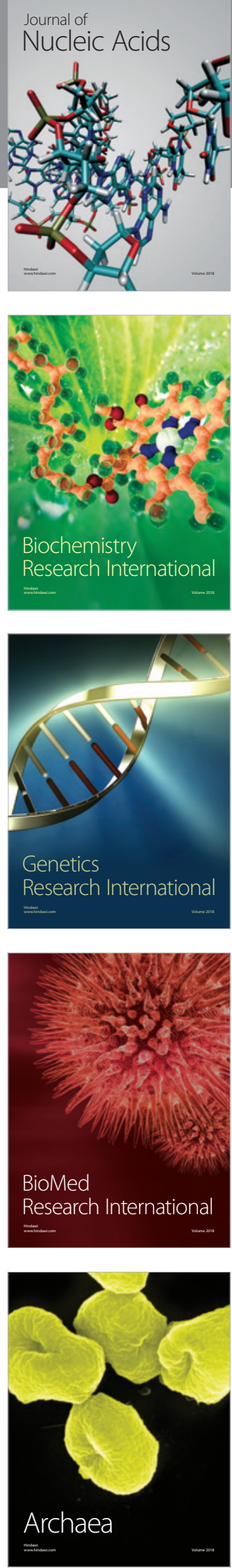